\title{
Revised predictive model for successful introduction of native Ohio brook trout (Salvelinus fontinalis) in select streams in Geauga and Lake counties, Ohio
}

KATHERINE SPRINGER AMEY', Geology Department, Kent State University, Kent, OH, USA

\begin{abstract}
Eight cold-water streams in Lake and Geauga Counties, Ohio were evaluated to revise a predictive model for assessing streams for future introduction of threatened native Ohio brook trout (Salvelinus fontinalis). A 15-month study was conducted in streams where brook trout were previously introduced during the years 1997-2002. Fifty percent of the 16 original reintroduction streams failed to support the establishment of self-sustaining populations of brook trout, indicating there were additional factors contributing to their success and failure. Of the eight streams included in this study, four streams were designated successful, two variable, and two failed in terms of the brook trout's ability to establish self-sustaining populations as defined by the Ohio Department of Natural Resources (ODNR). Multivariate statistical methods including principal component analysis (PCA) and agglomerative hierarchical cluster analysis (AHCA) identified the most important characteristics in brook trout stream selection. Factors found to be statistically significant for brook trout success include: 1) stream velocities within the range of 1.4 to $4.7 \mathrm{~cm} / \mathrm{s} ; 2$ ) high hydraulic conductivity of the headwater bedrock aquifer $\left.\left(K>4.7 \times 10^{3} \mathrm{~cm} / \mathrm{s}\right) ; 3\right)$ lighter average $\delta^{18} \mathrm{O} \%$ (-9.8 to -10.4$\left.) ; 4\right)$ either high percent canopy cover (40 percent to 55 percent) or high percent instream cover (18 to 37 percent); 5 ) abundant cold-water adapted benthic macroinvertebrate taxa (10 to 16 species); 6 ) yearly average hyporheic water temperature of $4.6^{\circ} \mathrm{C}$ to $17.2^{\circ} \mathrm{C}$; and 7) average surface water turbidity of 7 to $31 \mathrm{NTU}$. Long-term surface water temperature and dissolved oxygen monitoring over both winter and summer seasons is recommended prior to brook trout introduction to ensure their sustainability.
\end{abstract}

\section{INTRODUCTION}

By 1997, the state threatened native Ohio brook trout (Salvelinus fontinalis), was viable in only two small streams in the state. Prior to introduction to 16 northeast Ohio streams, the Ohio Department of Natural Resources (ODNR) developed a predictive model to evaluate critical stream characteristics necessary to support brook trout (Burt 2007: Table 1). Following brook trout introduction, a Habitat Suitability Index (HSI) model emerged with stream selection metricsimportant for successful reproduction identified by ODNR, Ohio Environmental Protection Agency (Ohio EPA), and the Geauga Park District (PJ Pira, AM Burt, and P Anderson, unpublished data, 2008). Brook trout failed to thrive in almost 50 percent of the streams in which it was introduced in Ohio, with varying outcomes of reproductive success, so further investigation was warranted.

The overall objective of this research was to develop a new predictive model built on the previous ODNR model of stream selection and subsequent HSI model. This revised predictive model would include additional

${ }^{1}$ Address correspondence to Katherine Springer Amey, Geology Department, 221McGilvrey Hall, Kent State Univeristy, Kent OH 44242. E-mail: kamey@ kent.edu parameters and be more reliable in identifying candidate streams for future Ohio brook trout introduction. To accomplish this objective, the study aimed to enhance the predictive metrics of the HSI model by further evaluating the hydrology, hydrogeology, biology, water

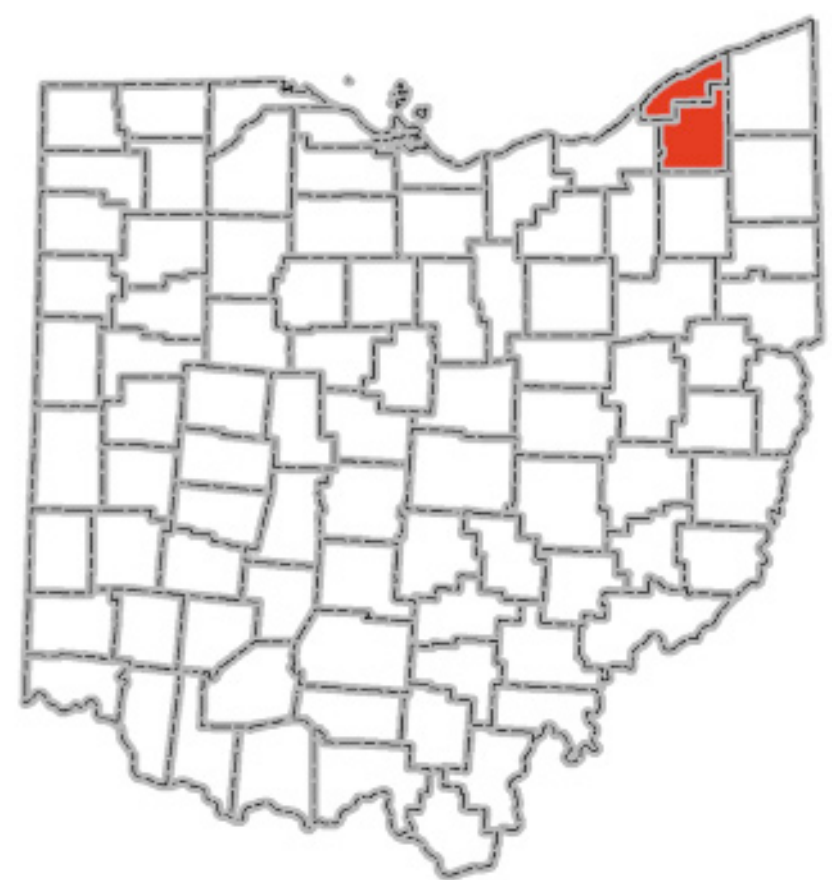

FIGURE 1. The location of Lake and Geauga counties, $\mathrm{OH}$. 
quality and habitat of eight of the existing 16 selected brook trout streams, seven in Geauga County and one in Lake County (Fig. 1).

Selecting investigative parameters for this study was based on several factors, including the necessity of continuous flow cold-water streams for the establishment of a self-sustaining brook trout population (Letcher et al. 2007). Paramount to brook trout viability is maintenance of stream temperature by influx of groundwater, in part through the hyporheic zone (the mixing zone between groundwater and surface water just beneath the stream bottom) (ConstantzandZellweger 1995). Thehyporheic zone is a critical ecological region, for even when visible flow above the streambed is not evident, there is water flowing in the hyporheic zone beneath the surface (Boulton et al. 1998). Flow through the head and tail of riffle zones is where brook trout are thought to have their spawningbeds or redds (Witzel and Maccrimmon 1983).

This study included similar parameters considered in the earlier HSI study and model (Pira et al., unpublished data, 2008); however, this study differs from the HSI in that continuous water temperature monitoring was completed, and dissolved oxygen (DO), $\mathrm{pH}$, specific conductance, and turbidity were measured consistently (monthly) for 15 months. As in the HSI study and model, physical habitat parameters were considered, such as stream width, thalweg depth, and pool depth. Furthermore, this research repeated a Headwater Macroinvertebrate Field Evaluation Index (HMFEI) study of streams biology by identifying the number of Ephemeroptera (mayfly), Plecoptera (stonefly), and Trichoptera (caddisfly) (EPT) taxa and cold-water taxa in order to compare to existing records. This research also expanded previous ODNR and HSI metrics by additional study of the headwater aquifer, streambed lithology, precipitation, interaction at the groundwater/ surface water interface of the hyporheic zone, biology, stream velocity, spring discharge, stable isotopes, instream cover and canopy cover, as well as chemical, biological, and environmental factors affecting brook trout populations.

Table 1

Comparison of predictive model used prior to brook trout introduction and HSI Metrics following brook trout introduction

ODNR Predictive Model Prior to Introduction

1. High quality cold headwater streams, with mid-isummer temperatures $<20^{\circ} \mathrm{C}$

2. Optimum stream habitat, evaluated by using the Qualitative Habitat Evaluation Index (QHEI) developed by Ohio Environmental Protection Agency (OEPA) for Ohio streams (Rankin 1989).

3. Biological assessment of the stream by an evaluation of the species headwater fish and aquatic insects present, both indicators of high water quality.

Summary of Metrics for HSI following introduction

HSI Habitat

$\uparrow$ percent Cobble (riffle/run) $>30$ percent

$\downarrow$ Gravel $<30$ percent

$\uparrow$ percent Redd habitat number per $200 \mathrm{ft}>5$

$\uparrow$ EPT Taxa $>=10$ HMFEI Score $>42$

$\uparrow$ Riffles: precent with redds $>60$ percent

$\downarrow$ Bankfull With Ave $>1.5,<4.5 \mathrm{~m}$

\section{HSI Water Chemistry}

$\downarrow$ Water Temp $<16^{\circ} \mathrm{C}$ summer seasonal median

$\uparrow$ DO 9.5-11.0 mg/l summer seasonal daytime median

$\uparrow \mathrm{NO} 2+\mathrm{N} 03>1.0 \mathrm{mg} / \mathrm{l}$ and $<2.0 \mathrm{mg} / \mathrm{l}$

$\downarrow$ Alkalinity $<130 \mathrm{mg} / 1$

$\downarrow \mathrm{K}, \mathrm{CA}, \mathrm{Mn}$

$\downarrow$ Specific Conductance $<450 \mu \mathrm{mhos} /$ com Proxy for TDS 


\section{MATERIALS AND METHODS}

All of the eight streams studied are located in the Chagrin River Watershed in northeastern Ohio. Three streams, Springbrook, Woodiebrook, and Leech, are direct tributaries to the upper Chagrin River and were deemed successful in terms of brook trout reproduction. Three of the study streams are tributaries to Silver Creek, a tributary to the Chagrin River: Pebblebrook, a successful stream; Affelder, a stream with mixed success initially (now considered successful); and Nature Center-West Woods, a failed stream. Mt. Glen Farms, considered at first to be a variable stream, has now been determined to be a failed stream, and Pierson Creek, a failed stream, are both tributaries to the East Branch of the Chagrin River (Fig. 2).

In order to study additional possible parameters contributing to brook trout success, various methods were used for sampling and monitoring the surface water streams, hyporheic zone, and springs (where present) of each of the eight streams. The bedrock geology of the outcrops varies between the streams, so field mapping

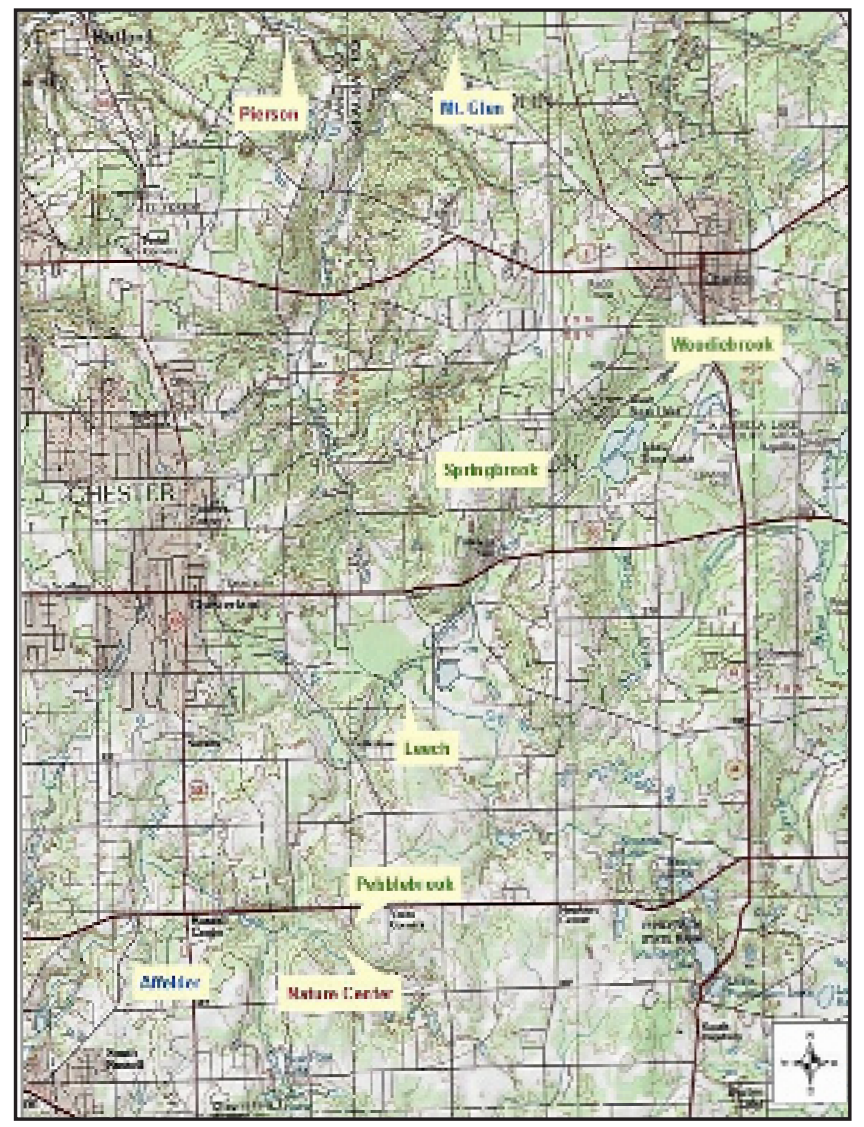

FIGURE 2. Location of headwater streams studies for brook trout introduction in Geauga and Lake counties, Ohio, and status regarding brook trout reproduction. Legend: green $=$ successful streams; blue = variable; red = failed. $\left({ }^{*}\right.$ Note: Mt. Glen changed from variable to unsuccessful and Affelder changed from variable to successful by the end of the study.) was completed to verify general geology of the area. Soil surveys were conducted and up to 50 soil cores per site from the banks and streambed of each of the eight streams were taken using a barrel auger, and field-analyzed using the Texture by Feel Procedure (USDA 1999). Using ODNR'son-line search tools, which are updated regularly, private drinking water well logs and their locations were obtained in order to analyze the local hydrogeology and determine the possiblelocation ofgroundwater discharge to the study streams. Hydraulic conductivities $(\mathrm{K})$ of the shallow bedrock aquifers of the streams were estimated from transmissivity ( $\mathrm{T}$ ) calculations by use of the Thiem equation (Bear 1979), and divided by the estimated aquifer saturated thickness (b) estimated from well logs. Stable isotopic composition of the hydrogeological system (streams, springs, hyporheic, and precipitation) was analyzed for oxygen $\delta^{18} \mathrm{O}$ and hydrogen $\delta^{2} \mathrm{H}$, for ratios of ${ }^{2} \mathrm{H} /{ }^{1} \mathrm{H}$ and ${ }^{18} \mathrm{O} /{ }^{16} \mathrm{O}$ in order to 'fingerprint' the source and quantity of the groundwater movingin the stream systems following IAEA (1997) technical procedures. Discharge in the eight streams was calculated with a SonTek/YSI FlowTracker, which utilizes the U.S. Geological Survey (USGS) method for wading discharge measurements (Rantz 1982). Spring discharge was measured with a stopwatch and a graduated cylinder directly at the source.

The interface of the hyporheic zone was monitored with mini-piezometers constructed out of $1.9 \mathrm{~cm}$ PVC1120 Schedule 40 . Whenever possible, up to $10 \mathrm{mini}-$ piezometers per stream were installed, in two nests of 30 , 60 and 90 centimeters deep, in the hyporheic zone of a riffle head and tail.

Continuous temperature readings of the surface and spring water were monitored with the $\mathrm{HOBO}^{\circ} \mathrm{U} 22$ Water Temp Pro v2 logger, and Dallas Thermochron iButtons DS1922 were used to monitor both the ambient air and water temperature in the mini-piezometers. An example of the typical output of continuous temperature monitoring of streams with perennial springs is shown in Figure 3. Surface waters demonstrated a larger range and higher short-term variability due to atmospheric influence and spring water temperatures displayed the lowest range and short-term variability because they are more representative of groundwater temperatures. Following placement of the continuous temperature monitoring equipment, monthly site visits were made to all 8 streams and a Horiba $U$ - 10 water quality meter was used to measure water temperatures in ${ }^{\circ} \mathrm{C}, \mathrm{pH}$, specific conductance $(\mathrm{mS} / \mathrm{cm})$, and turbidity (NTU) of the surface, hyporheic, and spring water. A YSI DO 200 Ecological meter was utilized to determine dissolved 
oxygen (ppm) and field temperatures.

Ohio EPA outlines the field methods used for the rapid bio-assessment of benthic macroinvertebrates using the Headwater Macroinvertebrates Field Evaluation Index (HMFEI) (Ohio EPA 2012). In 2005 Ohio EPA classified the cold-water streams selected for brook trout as Class III Primary Headwater Streams. Ohio EPA completed Primary Headwater Habitat (PHWH) Stream Evaluations, calculation of the Headwater Habitat Evaluation Index (HHEI), and the HMFEI scoring sheets June 2004 through September 2006 on all eight study streams. As part of this study, repeat HMFEI scores for the eight groundwater/surface water study streams were assessed in June and July 2009 , and the benthic macroinvertebrates, salamanders, and fish were sampled to determine the current biological integrity.

Over the course of one year, quarterly Ostracoda were sampled from all eight streams and springs in various habitats. Collection of the ostracodes within sediment samples was completed with a D-framenet. The samples were first weighed and washed, and sent through a set of three mesh sieves, $20(841 \mu \mathrm{m}), 100(149 \mu \mathrm{m})$, and $230(63 \mu \mathrm{m})$, to separate the 100 -mesh sediment containingostracodes for analysis. Between each sample, the sieves were cleaned in a Sonicator to prevent crosscontamination. The sample from each sieve was placed in a freezer in a labeled Whirlpak Bag. The sampleswere processed in the Virtis freeze dryer to remove any water in the sample and prepare for identification. Live samples at the time of collection have their carapace and body tissues intact and were separated with a fine paintbrush and placed on a micropaleontology slide and separated according to species.

Multivariate statistical methods were used to better determine significance of the many variables in this study. Principal component analysis (PCA) and agglomerative hierarchical cluster analysis (AHCA) were performed to determine the similarities and group the streams by success or failure to support brook trout. Adendrogram using the median weighted average linkage method with Gower's general coefficient of similarity shows how similar cases link together. Unconstrained cluster analysis was utilized in both median and centroid methods to join similar objects into clusters.

These statistical analyses were completed to account for the variance in the data, to identify independent variables and their proxies in the dataset, and to determine patterns of significance and similarities between streams. Eigenanalysis ordinations were calculated using Multi-Variate Statistical Package (MVSP) available from Kovach Computing Services. Centered and standardized data were used in PCA with each of the eight sites in order to calculate a correlation matrix and extract eigenvalues.

\section{RESULTS}

Table 2 is asummary of the additional successfulmetric

Woodiebrook Surface, Hyporheic, and Spring Water Temperature

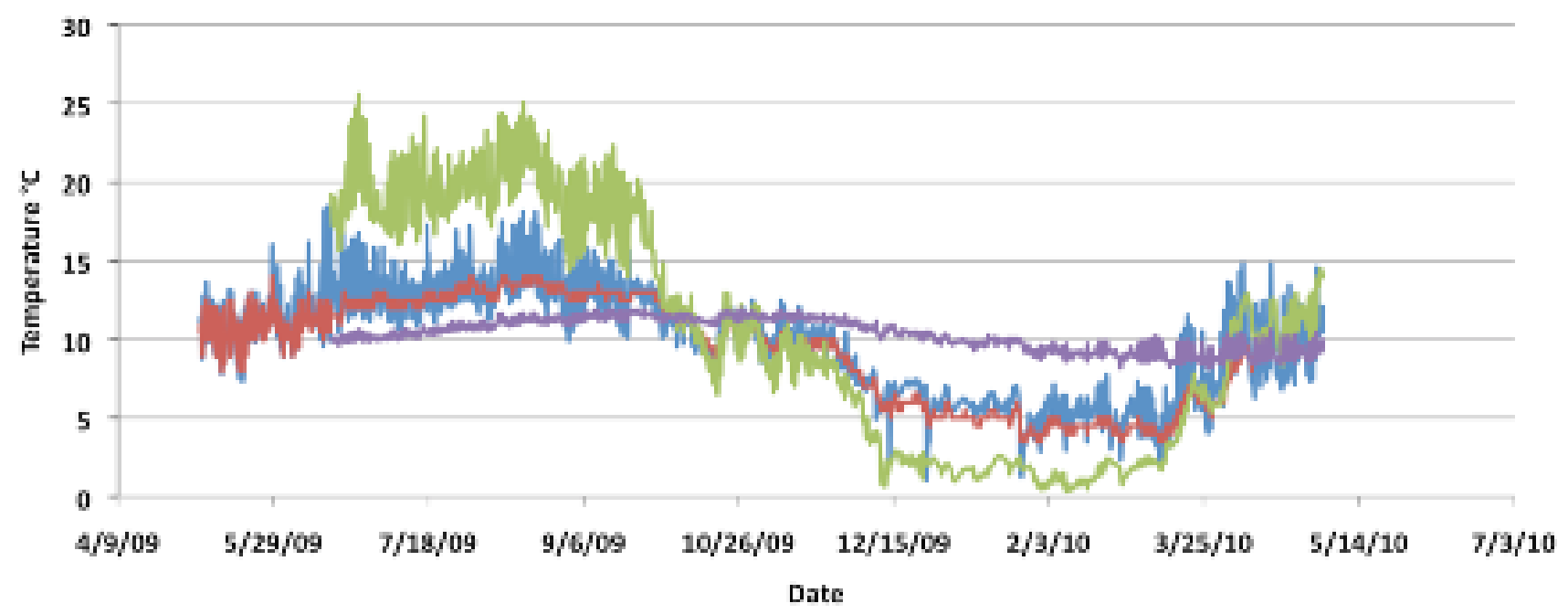

FIGURE 3. Example of plot of continuous water temperature monitoring at Woodiebrook stream surface, hyporheric and spring water temperature (4/2009 - 7/2010). Legend: blue = surface water temperature; red = hyperheic water temperature; green = tributary water temperature; black = spring water temperature. 
results for streams (cases) and variables (parameters) chosen for PCA analysis for comparing the eight study streams for the predictive brook trout introduction model. In addition, Table 2 lists additional qualities of successful streams for brook trout sustainability and parameters that are statistical proxies that may be interchanged to determine potential successful streams prior to introduction.

Centered and standardized variable data were used in PCA analysis with each of the eight cases in order to calculate a correlation matrix and extract eigenvalues. The first eigenvector, I, indicates that $\mathrm{pH}$ and specific conductance, number of ostracode species and cold water taxa, percent canopy cover, and corresponding maximum surface water temperatures account for 31 percent of the variance. Eigenvector II suggests that hydraulic conductivity $(\mathrm{K})$ of the headwaters and streams, HMFEI score and EPT taxa number, average stable isotope of oxygen of the surface water $\left(\delta^{18} \mathrm{O} \% \mathrm{o}\right)$, and related hyporheic waters accounts for 20 percent of the variance. Eigenvector III demonstrates that percent instream cover and average thalweg depth, mean velocity of the stream, and average DO accounts for 19 percent of the variance. Maximum hyporheic water temperature and the turbidity of the surface water account for 12 percent of the variance of Eigenvector IV. Together,

Table 2

Additional metrics incorporated into the predictive model for successful brook trout introduction

\begin{tabular}{|c|c|c|}
\hline Metric & Successful Range & Proxy \\
\hline Discharge $\mathrm{Q}=\mathrm{VA}\left(\mathrm{m}^{3} / \mathrm{s}\right)$ & $\begin{array}{l}3.68 \times 10^{-3} \text { to } 4.25 \times 10^{-3} \mathrm{~m}^{3} / \mathrm{s} \\
\left(0.13 \text { to } 0.51 \mathrm{ft}^{3} / \mathrm{s}\right) \\
\text { (Lower relative to failed) }\end{array}$ & Velocity (V) $1.4-4.7 \mathrm{~cm} / \mathrm{s}$ \\
\hline $\begin{array}{l}\text { Cold Water Macroinvertebrate } \\
\text { Taxa }\end{array}$ & $\begin{array}{l}10 \text { to } 15 \text { Species } \\
\text { (Higher Numbers) }\end{array}$ & $\begin{array}{l}\text { *Lower HMFEI Scores, } \\
\text { EPT Taxa and Ostracode \# }\end{array}$ \\
\hline Percent Canopy Cover & 40 to 55 Percent $(\mathrm{H})$ & \\
\hline $\begin{array}{l}\text { Headwater Hydraulic } \\
\text { Conductivity (HW K) }\end{array}$ & $\begin{array}{l}\left(4.7 \times 10^{3} \text { to } 14.2 \times 10^{3} \mathrm{~cm} / \mathrm{s}\right) \\
\text { (Higher Values) }\end{array}$ & $\begin{array}{l}{ }^{*} \text { Lower Streambed Hydraulic } \\
\text { Conductivity }(\mathrm{K})\end{array}$ \\
\hline $\begin{array}{l}\text { Minimum hyporheic } \\
\text { Water } \mathrm{T}\left({ }^{\circ} \mathrm{C}\right)\end{array}$ & $\begin{array}{l}1.00 \text { to } 8.50{ }^{\circ} \mathrm{C} \\
\text { (Higher Values) }\end{array}$ & $\begin{array}{l}\text { Higher Average Min. Hyporheic } \\
\text { Water } \mathrm{T}\left({ }^{\circ} \mathrm{C}\right)\end{array}$ \\
\hline Ave. $\delta 180 \%$ & $\begin{array}{l}-9.8 \text { to }-10.4 \text { (Lighter More } \\
\text { (Negative Values) }\end{array}$ & Lighter (more negative) $\delta \mathrm{D}$ \\
\hline Ave. Hyporheic DO (ppm) & $\begin{array}{l}4.08 \text { to } 7.39 \text { ppm (Lower Values } \\
\text {-lower than SW DO) }\end{array}$ & \\
\hline Percent Instream Cover & 18 to 37 Percent (Higher Values) & High Average Thalweg Depth \\
\hline Max Hyporheic Water T $\left({ }^{\circ} \mathrm{C}\right)$ & 14.0 to $26.5^{\circ} \mathrm{C}$ (Higher Values) & \\
\hline Ave. Turbidity SW (NTU) & 7 to 31 NTU (Lower Values) & \\
\hline
\end{tabular}

*Not to be used as parameters for Successful Brook Trout Stream Introduction 
the first three components explain 70 percent of the variance, and the first four components combine to 82 percent of the variance in the data. In other words, for the successful brook trout streams, these parameters account for the majority of the variance.

The dendrogram from AHCA determines the similarities and groups the streams by success or failure to support brook trout (Fig. 4). The dendrogram shows that successful streams tend to cluster based on their similar characteristics, with the exception of the one failed site (Nature Center).

\section{DISCUSSION}

The objective of this study was to develop a robust predictive model for brook trout habitat success in Ohio. The new model may be used in conjunction with the HSI for any stream that meets the conditions outlined here for native Ohio brook trout. In characterizing potential successful brook trout streams, the ODNR and HSI models both noted surface water temperature as crucial to brook trout survival.

In this study, continuous water temperature monitoring and average $\mathrm{DO}$ measurements throughout summer and winter seasons identified streams with prolonged water temperature extremes outside the average range of $1.0^{\circ} \mathrm{C}$ to $18.0^{\circ} \mathrm{C}$ and low $\mathrm{DO}$. In the hyporheic zone, at the head of the stream riffles, yearly average hyporheic water temperatures of $4.6^{\circ} \mathrm{C}-17.2^{\circ} \mathrm{C}$ were found to be statistically significant in the successfully sustaining brook trout in streams.

The headwater bedrock aquifer and springs supply the successful streams with groundwater runoff, discharging as both springs and seepage water directly, and comprise the baseflow. The successful brook trout streams, measured during summer low flow, when the streams were comprised of mainly baseflow, were found to be within a range of velocities of $1.4-4.7 \mathrm{~cm} / \mathrm{s}$. These successful streams exhibited lighter average $\delta^{18} \mathrm{O} \%$ in the range of -9.8 to -10.4 . This range is consistent with the average $\delta^{18} \mathrm{O} \%$ range of the springs, which influence the overall surface water discharge. The headwaters of successful streams, both with and without springs, were comprised of the high hydraulic conductivity Sharon Sandstone Conglomerate bedrock aquifer (K>4.7 x $10^{3} \mathrm{~cm} / \mathrm{s}$ ).

Stream habitat, including either high percent canopy cover ( 40 to 55 percent) or high percent instream cover (18 to 37 percent), was also indicative of brook trout success. Brook trout preferred areas toward pools and riffle heads of the streams, however, streambed composition was not an important factor. Sections of the main reach of several successful streams were insulated from the zone of saturation.

The HMFEI score and EPT taxa number of macroinvertebrates were found to be statistically significant in the HSI for successful brook trout stream populations. In this study, a high number of cold-water adapted benthic macroinvertebrates (10-16 species was indicative of successful streams. Conversely, a relatively low number of ostracodes, HMFEI score, and EPT taxa numbers were found in the successful streams, supplying a likely food source for brook trout.
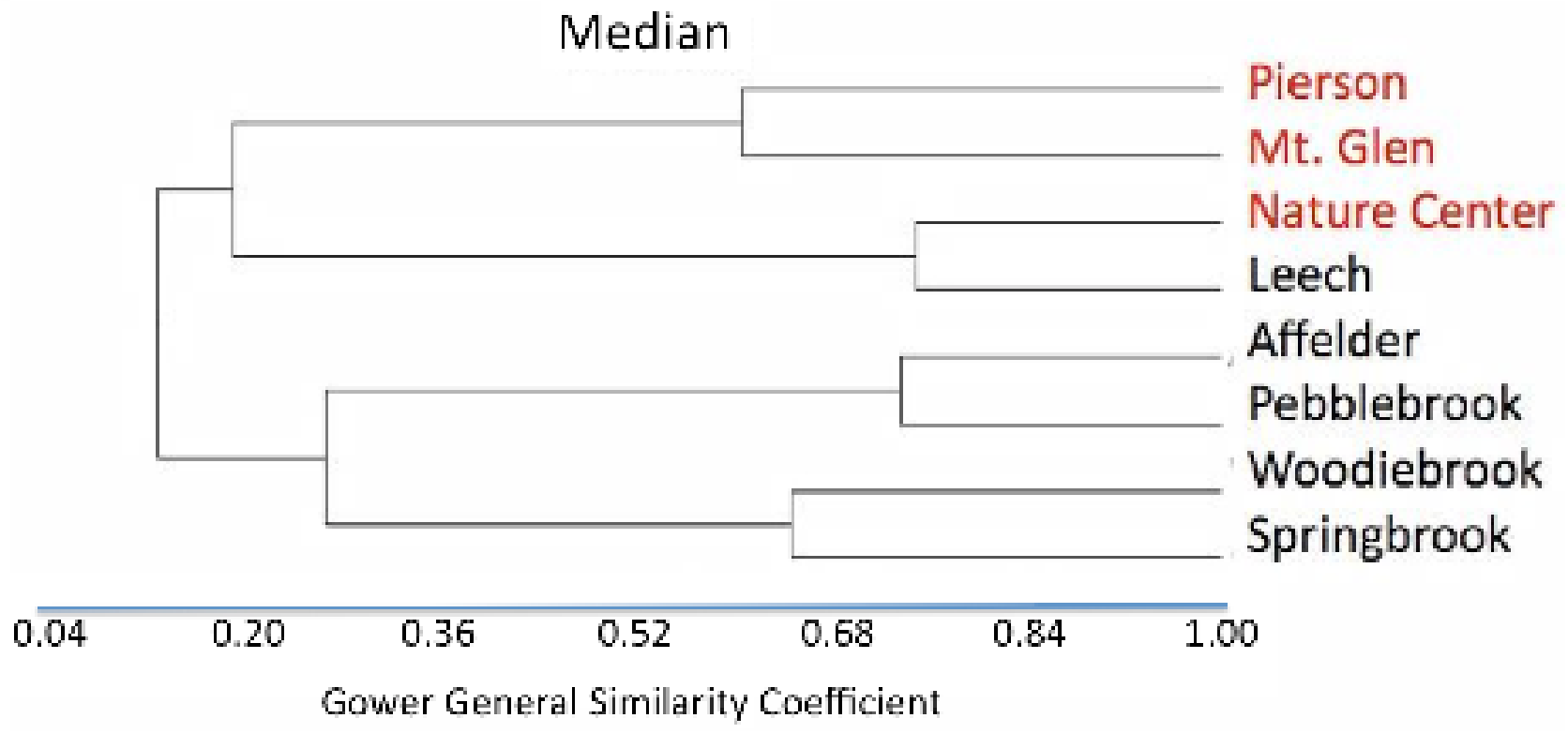

FIGURE 4: Cluster analysis using median (unconstrained) with Gower General Similarity Coefficient. Legend: Red names = failed streams; black names $=$ successful streams. 
Therefore, for potential stream selection and brook trout introduction, a high number of ostracodes and benthic macroinvertebrates would be good predictors of success. Even though lower scores were found in successful streams, all eight streams had relatively high HMFEI scores, indicating they are all excellentheadwater habitats for macroinvertebrates regardless of their ability to sustain brook trout. Repeated HMFEI surveys prove useful because if scores are lower than the past, they point to areas within the stream that might be in need of attention before the overall stream quality degrades.

Prior to introduction, consistent measurement of average turbidity resulting in seven to $31 \mathrm{NTU}$ of the surface water is a useful measure for brook trout that thrive in low silt streams with little erosion.

A simplified illustration of factors from this study that affect successful reintroduction is in Figure 5. The site characteristics influence the biology assemblages, the water chemistry, and the physical measurements. The physical measurements, such as water temperature and hydraulic conductivity, affect the chemical nature of the stream and thus the biology. The interactions are interdependent and a fragile balance exists in these surface systems.

A study of the lithology of the streambed and headwaters prior to brook trout introduction would be beneficial in choosing a locality. The subsurface plays a considerable role in the overall environmental surface system. The headwaters of these streams that sustain the brook trout are ecologically extremely fragile, and efforts towards protecting this sensitive species from extinction should be commended.

\section{ACKNOWLEDGMENTS}

I would like to thank my colleagues in preparation of this manuscript: Paul Anderson of EnviroScience, Dr. Atiur Rahman and Conni McCambridge of Ohio EPA. I would alsolike to thank the Geauga Park District for their financial support and access to a majority of the brook trout streams as well as Holden Arboretum in Lake County for access to Pierson Creek. The Ohio Department of Natural Resources and Brook Trout Unlimited provided invaluable information and support for the research. Lastly I would like to thank Kent State

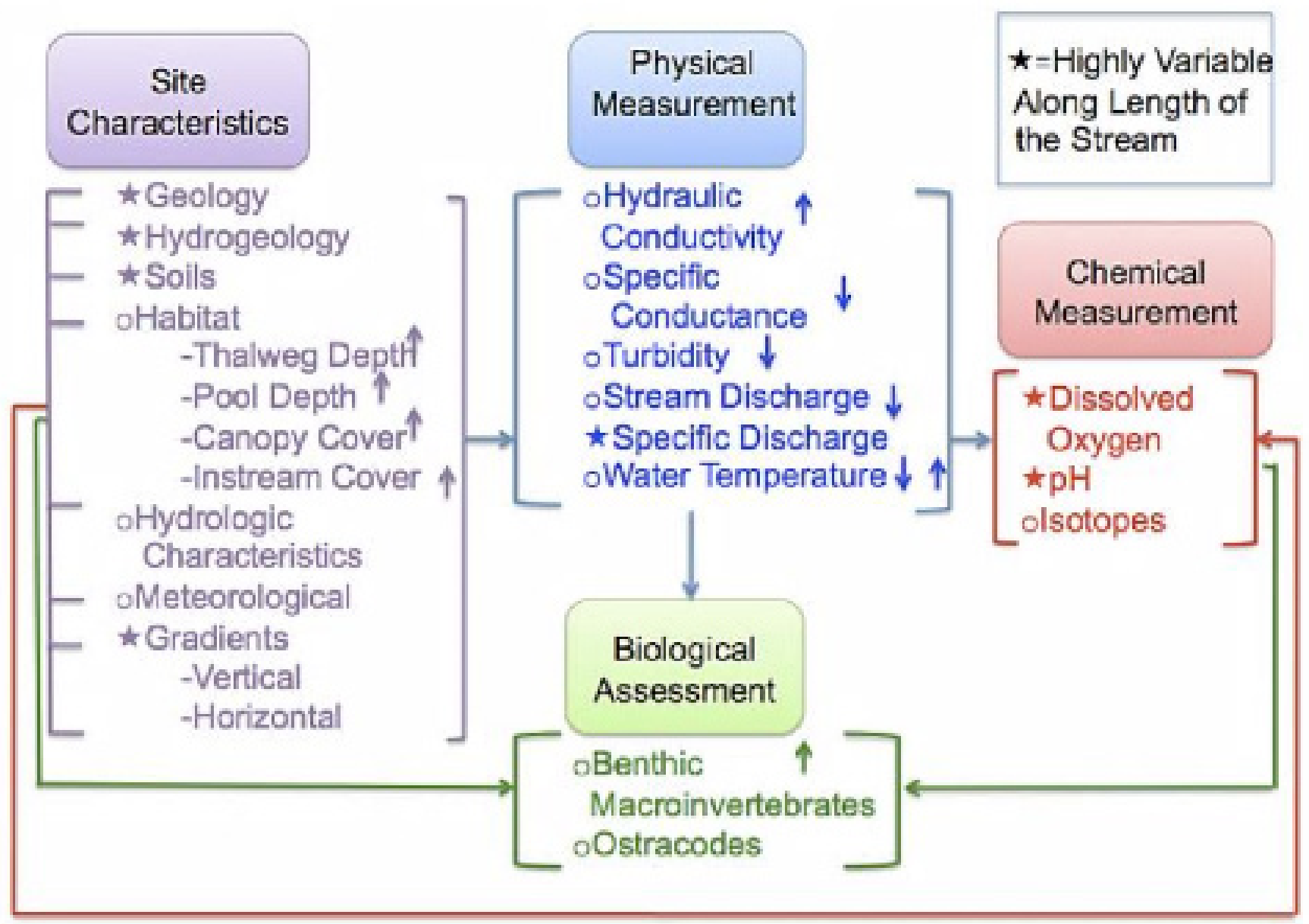

FIGURE 5: Factors that affect reintroduction into trout streams in northeast Ohio. The factors are often highly interdependent on one another. 
University for providing the opportunity for this study. This paper is derived from research from the doctoral dissertation: Amey, K. 2011. Hydrology and predictive model of headwater streams and the groundwater/ surface water interactions supporting brook trout habitat in northeast Ohio [dissertation]. [Kent $(\mathrm{OH})]$ : Kent State University.

\section{LITERATURE CITED}

BearJ. 1979. Hydraulics of groundwater. New York (NY): McGraw Hill; p. 241.

Boulton AJ, Findlay S, Marmonier P, Stanley EH, Valetti HM. 1998. The functional significance of the hyporheic zone in streams and rivers. Ann Rev Ecol Syst. 29: 59-81.

Burt A. 2007. Project final report: brook trout reintroduction: Lake Erie drainage, NE Ohio. Report no.: F3SM02 .[accessed 2014 Sept 10]. http://tumadmen.org/assets/documents/ ODNR\%20Brook\%20Trout\%20Final\%20Report.pdf.

Constantz J, Zellweger G. 1995. Relations between stream temperature, discharge, and stream/groundwater interaction along several mountain streams In: Guy BT, Barnard, J, editors. Mountain hydrology: peaks and valleys in research and applications: proceedings of a conference held May 16-19, 1995 in Vancouver, B.C., Canada Water Resources Association. p. 79-85.

International Atomic Energy Agency (IAEA). 1997. Technical procedure for cumulative monthly sampling of precipitation for isotopic analyses; [accessed 2014Sept 10]. http://www-naweb. iaea.org/NAALIHL/docs/tech_info/Precipitation $\% 20$ Sampling97.pdf .

Letcher BH, Nislow KH, Coombs JA, O’Donnell MJ, Dubreuil TL. 2007. Population response to habitat fragmentation in a stream-dwelling brook trout population. PLoS ONE [accessed 2014Apr20];2(11):1-11.doi:10.1371/journal.pone.0001139.

Ohio Environmental Protection Agency (Ohio EPA). 2012. Field evaluation manual for Ohio's primary headwater habitat streams. Version 3.0. Columbus (OH): Ohio EPA Division of Surface Water; [accessed 2014 Apr 20]. http://www.epa.ohio.gov/ portals/35/wqs/headwaters/phwhmanual_2012.pdf.

Rankin ET.1989. The Qualitative Habitat Evaluation Index (QHEI): rationale, methods and application. Columbus (OH): Ohio EPA; [accessed 2014 Sept 10]. http://www.epa. ohio.gov/portals/35/documents/BioCrit88_QHEIIntro.pdf.

_Rantz, S.E., and others. 1982. Measurement and computation of streamflow volume 1 . Measurement of stage and discharge Volume 2.computation of discharge. Washington (DC): U.S. Geological Survey. [updated 2011 Jan 11; accessed 2014 Sept 10]. http://pubs.usgs.gov/wsp/wsp2175/

U.S. Department of Agriculture (USDA) 1999. Soil quality test kit guide. Washington (DC): US Department of Agriculture; [accessed 2014Sept 10].http://www.nrcs.usda.gov/Internet/ FSE_DOCUMENTS/stelprdb1044790.pdf.

Witzel LD, Maccrimmon HR. 1983 Redd-site selection by brook trout and brown trout in southwestern Ontario streams. Trans Amer Fish Soc 112(6): 760-771. doi: 0.1577/1548-8659(1983)112<760:RSBBTA>2.0.CO;2 